\title{
Uji Potensi Ekstrak Daun Biduri (Calotropis gigantea) sebagai Akarisida terhadap Infestasi Gurem (Ornithonyssus bursa) pada Ayam Buras
}

\section{Test Potency of Biduri Leaf Extract (Calotropis gigantea) as Acariside to Infestation of Tropical Fowl Mite (Ornithonyssus bursa) on Kampong Chicken}

\author{
Virgilius Martin Kelake Kedang1*, Rama Adi Rianto ${ }^{1}$, Idho Anugrah Al Kholik ${ }^{1}$, Upik \\ Kesumawati Hadi ${ }^{2}$ \\ ${ }^{1}$ Program Sarjana Kedokteran Hewan, ${ }^{2}$ Bagian Parasitologi dan Entomologi Kesehatan \\ Fakultas Kedokteran Hewan, Institut Pertanian Bogor \\ Jl. Agathis Kampus IPB Dramaga, Bogor, Jawa Barat 16680 \\ *Corresponding author: kedangvmk@gmail.com
}

\begin{abstract}
Abstrak
Infestasi ektoparasit merupakan salah satu masalah serius di bidang peternakan. Infestasi ektoparasit terbukti dapat menurunkan produktivitas ternak dan dapat menyebabkan kematian yang berdampak pada kerugian peternak. Salah satu ektoparasit yang sering menginfestasi ayam buras adalah gurem (Ornithonyssus bursa). Biduri (Calotropis gigantea) merupakan salah satu tanaman obat yang berpotensi untuk dikembangkan sebagai bioakarisida. Penelitian ini bertujuan untuk mengetahui potensi ekstrak daun biduri sebagai bioakarisida dalam mengendalikan infestasi gurem pada ayam buras. Ayam buras yang terinfestasi gurem secara alami dikelompokkan ke dalam lima kelompok masing-masing terdiri atas tiga ekor ayam. Perlakuan yang diuji dalam penelitian ini adalah larutan ekstrak daun biduri dengan konsentrasi 2 g/l, 4 g/l, dan 6 g/l, kontrol positif dengan sipermetrin $2 \mathrm{~g} / \mathrm{l}$, dan kontrol negatif dengan hanya pemberian air. Pengujian akarisida dilakukan dengan menggunakan metode dipping. Pengamatan gurem dilakukan sebelum pengujian, 24 jam setelah pengujian, 48 jam setelah pengujian, dan 72 jam setelah pengujian. Gurem dihitung dengan menggunakan counter berdasarkan regio tubuh ayam. Hasil yang diperoleh kemudian dianalisis dengan analisis ragam sidik. Pengamatan perilaku menelisik bulu dilakukan dengan menggunakan metode scan sampling. Frekuensi perilaku menelisik bulu dihitung dan dianalisis secara deskriptif. Hasil perlakuan ekstrak daun biduri dengan persentase reduksi gurem dan aktivitas menelisik bulu tertinggi berpotensi sebagai akarisida terhadap infestasi gurem pada ayam buras.
\end{abstract}

Kata kunci: akarisida, ayam buras, biduri, Ornithonyssus bursa

\begin{abstract}
The infestation of ectoparasites is one of the serious problem in poultry. Ectoparasites' infestation could decrease livestock productivity and causes death that damaged to farmers. One of the ectoparasites that mostly infest kampong chicken is tropical fowl mite (Ornithonyssus bursa). Biduri (Calotropis gigantea) is one of potential plants for bioacariside. This study aimed to determine the potency of biduri leaf extract as bioacariside to infestation of tropical fowl mite on kampong chicken. Kampong chicken that naturally infested with tropical fowl mite were divided into five groups, each group consist of three chickens, respectively the treatments used in this study were biduri leaf extract solution with three different concentrations, which are 2 $\mathrm{g} / \mathrm{l}, 4 \mathrm{~g} / \mathrm{l}$, and $6 \mathrm{~g} / \mathrm{l}$, cypermethrin $2 \mathrm{~g} / \mathrm{l}$ as positive control, and aquades as negative control. Acariside treatment used dipping method. The observation of tropical fowl mite were performed before treatment, 24 hours after treatment, 48 hours after treatment, and 72 hours after treatment. Tropical fowl mite were counted with counter based on body regions of the chicken. Results were analyzed using analysis of variance. The observation of grooming activity used scan sampling method. Frequency of grooming activity were counted and analyzed descriptively. The results of biduri leaf extract treatment with the highest percentage of tropical fowl mite reduction and the highest percentage of grooming activity reduction were potentially as acariside to treat tropical fowl mite infestation on kampong chicken.
\end{abstract}

Keywords: acariside, biduri, kampong chicken, Ornithonyssus bursa

Received: 19 April 2020

Revised: 8 Mei 2020

Accepted: 22 Mei 2020 


\section{PENDAHULUAN}

Ektoparasit adalah parasit yang hidup di bagian luar atau permukaan tubuh inangnya. Ektoparasit menjadi salah satu masalah serius yang sering dihadapi oleh para peternak. Infestasi ektoparasit terbukti menurunkan produktivitas ternak dan dapat menyebabkan kematian yang berdampak pada kerugian peternak. Suhu, lingkungan, kontak antar spesies yang sakit, dan sistem peternakan yang kurang efektif turut berpengaruh terhadap penyebaran ektoparasit (Hadi dan Soviana, 2010).

Salah satu ektoparasit yang sering menyerang ayam buras adalah gurem (Ornithonyssus bursa). Gurem sering disebut juga tungau burung, tungau tropis, tungau starling, dan sieur. Gurem merupakan tungau ektoparasit yang memiliki ciri khas yaitu sering menyerang ayam ketika sedang mengerami telurnya. Infestasi gurem dapat mengakibatkan penurunan produktivitas ayam buras hingga lebih dari $25 \%$ dan pada anak ayam usia kurang dari satu bulan dapat menyebabkan kematian (KEMENTAN, 2014). Pemeliharaan ayam yang masih kurang efektif menjadi salah satu penyebab gurem dapat berpindah dengan mudah dari satu inang ke inang yang lain.

Berbagai upaya dilakukan untuk mencegah hingga mengendalikan infestasi gurem. Pencegahan dapat dilakukan dengan menjaga kebersihan kandang khususnya tempat pengeraman ayam. Kandang diusahakan tetap kering, sirkulasi udara baik, dan sinar matahari dapat masuk ke kandang. Pengendalian gurem dapat dilakukan dengan penggunaan akarisida. Akarisida adalah kelompok pestisida yang digunakan untuk membasmi ektoparasit kelompok akari seperti tungau dan caplak. Akarisida yang sering digunakan oleh para peternak adalah akarisida sintetik seperti sipermetrin, kumafos, karbaril, dan malathion (KEMENTAN, 2014).

Penggunaan akarisida sintetik yang intensif dapat menimbulkan dampak negatif berupa resistensi tungau terhadap akarisida, residu yang tertinggal di daging dan telur, pencemaran lingkungan, dan matinya musuh alami parasit. Dampak negatif penggunaan akarisida sintetik mengakibatkan akarisida sintetik perlu ditekan penggunaannya dan digantikan dengan bioakarisida. Bioakarisida adalah akarisida yang berasal dari bahan alam dengan efektivitas tinggi, ramah lingkungan, memiliki target spesifik, dan toksisitas yang rendah.

Ketersediaan akarisida di Indonesia yang telah diuji khasiatnya secara ilmiah masih terbatas. Penelitian terkait potensi bahan alam tertentu sebagai bioakarisida juga masih sangat terbatas. Beberapa penelitian kini sedang gencar mengeksplorasi tumbuhan-tumbuhan obat berdasarkan kearifan lokal dari komunitas masyarakat tertentu. Eksplorasi tanaman obat berdasarkan kearifan lokal menjadi hal yang menarik untuk diteliti. Eksplorasi tersebut diharapkan dapat menemukan kandungan senyawa penting pada beberapa tumbuhan yang berpotensi untuk dikembangkan menjadi bahan obat-obatan tertentu, tak terkecuali bagi hewan khususnya sebagai bioakarisida. Tumbuhan potensial yang dapat dikembangkan menjadi bioakarisida adalah tanaman biduri (Calotropis gigantea). Tanaman biduri dipercaya oleh masyarakat di Kabupaten Lembata sebagai tumbuhan yang dapat digunakan untuk mengusir tungau parasit yang kerap hidup di ayam yang sedang dalam masa mengerami telurnya. Parasit yang memiliki ciri khas muncul ketika ayam sedang dalam masa mengerami telur adalah gurem (Ornithonyssus bursa). Penelitian ini bertujuan untuk mengetahui potensi ekstrak daun biduri sebagai bioakarisida dalam mengendalikan infestasi gurem pada ayam buras.

\section{METODE PENELITIAN}

\section{Waktu dan Tempat Penelitian}

Penelitian dilaksanakan pada bulan April sampai Juni 2019. Identifikasi sampel ektoparasit dilakukan di Laboratorium Entomologi Fakultas Kedokteran Hewan IPB. Pembuatan ekstrak daun biduri dilakukan di Laboratorium Farmasi Veteriner Fakultas Kedokteran Hewan IPB dan Pusat Antar Universitas IPB. Penapisan fitokimia dilakukan 
di Balai Penelitian Tanaman Rempah dan Obat Kementerian Pertanian. Pengujian akarisida dilakukan di Laboratorium Lapang Ilmu Nutrisi Ternak Unggas Fakultas Peternakan IPB.

\section{Persetujuan Etik Hewan}

Setiap penelitian yang menggunakan hewan sebagai objek penelitian harus mendapatkan persetujuan dari Komisi Etik Hewan demi menjamin kesejahteraan hewan coba. Penelitian ini telah mendapatkan sertifikat persetujuan etik hewan dari Komisi Etik Hewan IPB Nomor: 129/KEH/SKE/V/2019.

\section{Ekstraksi Daun Biduri}

Bahan tanaman yang diambil adalah daun setengah tua dari tanaman biduri (Calotropis gigantea). Daun yang dipetik dibersihkan dengan air, dipotong, dan dikeringkan. Daun biduri selanjutnya ditimbang berat keringnya kemudian dihaluskan. Simplisia daun biduri sebanyak satu kilogram kemudian diekstraksi dengan teknik maserasi menggunakan penyari etanol 70\% sebanyak 10 liter selama 24 jam. Maserat pertama dipisahkan, dan ampas yang diperoleh diremaserasi hingga didapatkan maserat kedua dan maserat ketiga. Maserat digabungkan lalu diuapkan menggunakan rotary evaporator dengan suhu $40^{\circ} \mathrm{C}$ dan tekanan 175 mbar hingga diperoleh ekstrak kental daun biduri. Ekstrak daun biduri yang telah diperoleh kemudian dilakukan uji kualitatif terhadap senyawa alkaloid, saponin, tanin, fenolik, flavonoid, triterpenoid, steroid, dan glikosida.

\section{Koleksi dan Identifikasi Sampel Ektoparasit}

Koleksi dan identifikasi sampel ektoparasit dilakukan terlebih dahulu untuk memastikan sampel yang berasal dari ayam buras yang akan diuji adalah gurem (Ornithonyssus bursa). Sampel ektoparasit yang didapat dari ayam buras diperoleh dari peternakan ayam buras di Dramaga, Bogor. Sampel dikoleksi dengan menyisir bulu sekitar ekor dan badan ayam buras. Ektoparasit yang ditemukan ditaruh dalam vial berisi alkohol $70 \%$ untuk selanjutnya dipreservasi dalam bentuk preparat untuk diidentifikasi. Preparat dilabeli kemudian diidentifikasi menggunakan mikroskop berdasarkan bentuk morfologi dengan menggunakan kunci identifikasi ektoparasit (Krantz 1978).

\section{Pemeliharaan Hewan Coba}

Hewan coba yang digunakan dalam penelitian adalah ayam buras betina umur 24 minggu sebanyak 15 ekor. Ayam dipelihara dalam lima buah kandang terpisah berukuran 1.5 $\mathrm{m} \times 1.5 \mathrm{~m}$. Kandang diberi sekat antar ayam dalam kelompok yang sama untuk mencegah perpindahan gurem. Keseluruhan ayam terinfestasi gurem secara alami sebelum dikandangkan. Ayam dikelompokan dalam 5 kelompok sesuai perlakuan, dengan masingmasing kelompok terdiri dari tiga ekor ayam. Aklimatisasi ayam sebelum pengujian dilakukan selama 7 hari untuk menyesuaikan kondisi ayam terhadap lingkungan kandang. Selama penelitian ayam diberi pakan dan minum ad libitum.

\section{Pengujian Akarisida}

Sebelum pengujian, masing-masing ayam dihitung jumlah gurem dengan melakukan observasi di regio leher, punggung, dada, sayap, dan ekor. Jumlah gurem di setiap regio dihitung menggunakan counter selama 2 menit. Pengujian menggunakan lima perlakuan berbeda yaitu P1 dengan ekstrak daun biduri $2 \mathrm{~g} / \mathrm{L}, \mathrm{P} 2$ dengan ekstrak daun biduri $4 \mathrm{~g} / \mathrm{L}, \mathrm{P} 3$ dengan ekstrak daun biduri $6 \mathrm{~g} / \mathrm{L}$, kontrol positif $(\mathrm{K}+)$ dengan sipermetrin $2 \mathrm{~g} / \mathrm{L}$, dan kontrol negatif (K-) dengan aquades.

Pengujian dilakukan dengan metode dipping yaitu mencelupkan seluruh bagian tubuh ayam kecuali bagian kepala ke dalam larutan sesuai perlakuan selama 2 menit (Axtell dan Arends, 1990). Observasi dilakukan 24 jam, 48 jam, dan 72 jam setelah perlakuan dengan menghitung kembali jumlah gurem setiap regio yang terdapat pada ayam.

\section{Pengamatan Perilaku}

Pengamatan perilaku menggunakan metode scan sampling dengan mengamati jumlah aktivitas ayam yang melakukan tingkah laku yang akan diamati. Perilaku yang diamati adalah 
perilaku preening atau menelisik bulu. Pengamatan dilakukan sebanyak tiga kali sehari yaitu pagi pukul 07.00-08.00, siang pukul 12.0013.00, dan sore pukul 16.00-17.00, dengan tiga kali pengulangan. Frekuensi aktivitas preening selama pengamatan pada setiap kelompok perlakuan ayam dicatat sesuai waktu. Pengamatan dilaksanakan sebelum pengujian akarisida dan setelah pengujian akarisida.

\section{Analisis Data}

Hasil pengujian akarisida dihitung persentase reduksi gurem kemudian dianalisis dengan analisis sidik ragam (ANOVA) dan dilanjutkan dengan uji Tukey. Hasil pengamatan perilaku dihitung persentase reduksi aktivitas menelisik bulu dan dianalisis secara deskriptif.

\section{HASIL DAN PEMBAHASAN}

\section{Hasil Penapisan Fitokimia}

Hasil penapisan fitokimia yang disajikan pada Tabel 1 menunjukan kandungan senyawa yang terdapat dalam ekstrak daun biduri positif mengandung alkaloid, saponin, tanin, fenolik, flavonoid, triterpenoid, steroid, dan glikosida. Kandungan senyawa ini sesuai dengan kandungan senyawa dalam daun biduri yang diteliti oleh Kumar et al. (2013) dan Hasyim et al. (2017). Kandungan senyawa yang terdapat dalam daun biduri tersebut berpotensi digunakan sebagai bioakarisida.

\section{Hasil Pengujian Akarisida}

Hasil pengujian akarisida menunjukan masing-masing perlakuan baik perlakuan ekstrak maupun kontrol dapat menurunkan populasi gurem. Rataan jumlah gurem setelah pengujian pada setiap perlakuan ekstrak daun biduri memiliki perbedaan nyata terhadap kontrol negatif (Tabel 2). Persentase penurunan jumlah gurem tertinggi dalam 24 jam terdapat pada kelompok perlakuan ekstrak daun biduri $6 \mathrm{~g} / \mathrm{l}$ (P3) yaitu sebanyak 95.13\% (Gambar 1). Persentase penurunan jumlah gurem sebanyak $100 \%$ didapati setelah 48 jam pada kelompok perlakuan ekstrak daun biduri 6 g/l (P3) dan kontrol positif. Persentase reduksi gurem hingga
100\% setelah 72 jam didapati pada kelompok ekstrak daun biduri 6 g/l (P3) dan 4 g/l (P2), serta kelompok kontrol positif $(\mathrm{K}+)$. Menurut KOMPES (2012) kelompok pestisida dinilai efektif jika mampu mereduksi serangga target dengan nilai reduksi hingga $>90 \%$ dalam 24 jam.

Ekstrak daun biduri yang diuji pada penelitian ini efektif dan berpotensi sebagai bioakarisida terhadap infestasi gurem pada ayam buras karena mampu mereduksi jumlah gurem hingga $>90 \%$ dalam 24 jam. Konsentrasi ekstrak daun biduri 6 g/l (P3) dapat dikembangkan menjadi bioakarisida karena memiliki daya reduksi gurem tertinggi hingga lebih dari $95 \%$ dalam 24 jam dan mencapai 100\% dalam 48 jam. Daya reduksi gurem perlakuan ekstrak daun biduri $6 \mathrm{~g} / 1$ mampu menyamai daya reduksi kontrol positif berupa akarisida sintetik sipermetrin.

Sipermetrin yang digunakan sebagai kontrol positif dalam penelitian ini merupakan akarisida sintetik dengan cara kerja spesifik sebagai racun perut dan racun kontak terhadap serangga target (Dirganaya et al., 2017). Efektivitas sipermetrin dalam konsentrasi rendah untuk pengendalian infestasi ektoparasit telah dibuktikan pada beberapa penelitian. Penelitian dari Setiawan (2013) membuktikan aplikasi sipermetrin $0.5 \mathrm{~g} / \mathrm{l}$ terhadap kutu Menopon gallinae pada ayam petelur mampu mereduksi populasi kutu hingga $100 \%$ dalam 24 jam. Prelezov (2008) melaporkan sipermetrin konsentrasi $100 \mathrm{~g} / \mathrm{l}$ mampu mengendalikan populasi ektoparasit di ayam hingga 100\% dalam 6 jam. Penggunaan sipermetrin pada sapi dengan konsentrasi $3 \mathrm{~g} / \mathrm{l}$ mampu mengendalikan infestasi caplak Boophilus microplus (Nugroho, 2014). Persentase reduksi gurem pada perlakuan ekstrak daun biduri yang mampu menyamai efektivitas dari akarisida sintetik membuktikan daun biduri berpotensi dikembangkan menjadi bioakarisida.

Penurunan jumlah gurem pada perlakuan konsentrasi ekstrak daun biduri disebabkan oleh zat-zat aktif yang terkandung di dalam ekstrak daun biduri. Kandungan flavonoid, saponin, tanin, fenol, triterpenoid, dan alkaloid yang terdapat dalam daun biduri dapat berfungsi sebagai bioakarisida (Hasyim et al., 2017). 
Tabel 1. Hasil penapisan fitokimia

\begin{tabular}{lc}
\hline Golongan Senyawa & Hasil Uji \\
\hline Alkaloid & + \\
Saponin & + \\
Tanin & + \\
Fenolik & + \\
Flavonoid & + \\
Triterpenoid & + \\
Steroid & + \\
Glikosida & + \\
\hline
\end{tabular}

Tabel 2. Persentase reduksi gurem setelah pengujian akarisida

\begin{tabular}{cccc}
\hline Konsentrasi Ekstrak & \multicolumn{3}{c}{ Persentase reduksi gurem setelah pengujian $(\%)$} \\
\cline { 2 - 4 } Daun Biduri & $\mathbf{2 4}$ jam & $\mathbf{4 8}$ jam & $\mathbf{7 2}$ jam \\
\hline 2 g/l (P1) & $85.39 \pm 6.09^{\mathrm{a}}$ & $89.58 \pm 7.37^{\mathrm{b}}$ & $92.66 \pm 1.45^{\mathrm{b}}$ \\
$4 \mathrm{~g} / \mathrm{l}(\mathrm{P} 2)$ & $92.64 \pm 2.10^{\mathrm{a}}$ & $96.70 \pm 0.37^{\mathrm{b}}$ & $100.00 \pm 0.00^{\mathrm{a}}$ \\
6 g/l (P3) & $95.13 \pm 1.53^{\mathrm{a}}$ & $100.00 \pm 0.00^{\mathrm{a}}$ & $100.00 \pm 0.00^{\mathrm{a}}$ \\
Kontrol Positif & $94.81 \pm 1.80^{\mathrm{a}}$ & $100.00 \pm 0.00^{\mathrm{a}}$ & $100.00 \pm 0.00^{\mathrm{a}}$ \\
Kontrol Negatif & $19.83 \pm 8.15^{\mathrm{b}}$ & $27.95 \pm 3.57^{\mathrm{c}}$ & $34.01 \pm 3.99^{\mathrm{c}}$ \\
\hline
\end{tabular}

Keterangan: Superksrip berbeda pada kolom yang sama menyatakan pengaruh yang nyata $(\mathrm{p}<0.05)$

Tabel 3. Frekuensi perilaku preening sebelum dan sesudah pengujian

\begin{tabular}{cccc}
\hline \multirow{2}{*}{$\begin{array}{c}\text { Konsentrasi Ekstrak } \\
\text { Daun Biduri }\end{array}$} & \multicolumn{2}{c}{$\begin{array}{c}\text { Frekuensi rata-rata jumlah aktivitas } \\
\text { preening dalam satu jam (3 ekor) }\end{array}$} & $\begin{array}{c}\text { Persentase reduksi } \\
\text { aktivitas preening }(\%)\end{array}$ \\
\cline { 2 - 3 } & Sebelum pengujian & Setelah pengujian & \\
\hline 2 g/l (P1) & $29.00 \pm 17.82$ & $9.22 \pm 4.40$ & $68.02 \pm 5.11^{\mathrm{b}}$ \\
4 g/l (P2) & $24.22 \pm 11.84$ & $7.11 \pm 6.09$ & $70.89 \pm 3.43^{\mathrm{b}}$ \\
6 g/l (P3) & $26.89 \pm 12.66$ & $4.44 \pm 2.12$ & $83.81 \pm 3.10^{\mathrm{a}}$ \\
Kontrol Positif & $33.67 \pm 5.67$ & $4.67 \pm 2.55$ & $86.15 \pm 2.81^{\mathrm{a}}$ \\
Kontrol Negatif & $21.44 \pm 10.99$ & $13.89 \pm 8.00$ & $34.63 \pm 3.46^{\mathrm{c}}$ \\
\hline
\end{tabular}

Keterangan: Superksrip berbeda pada kolom yang sama menyatakan pengaruh yang nyata $(\mathrm{p}<0.05)$

Zat aktif yang terkandung dalam daun biduri yaitu saponin bersifat racun perut dan racun pernapasan bagi serangga sehingga dapat digunakan sebagai pembasmi serangga. Saponin juga dapat merendahkan tegangan permukaan, merusak membran sel, dan menganggu proses metabolisme serangga (Haditomo, 2010). Zat aktif lainnya berupa tanin berpengaruh terhadap tekanan osmotik sel ektoparasit sehingga sel mengkerut dan mengakibatkan ektoparasit mati (Anggraini, 2006). Flavonoid yang terkandung dalam daun biduri bersifat sebagai inhibitor pernafasan dan menganggu mekanisme energi di mitokondria dengan menghambat sistem pengangkutan elektron (Agnetha, 2008). Senyawa lainnya seperti fenol, triterpenoid, alkaloid, dan steroid berperan sebagai antifeedant atau menghambat proses makan parasit (Widawati dan Prasetyowati, 2013). Hasil penelitian ini sejalan dengan studi yang dilakukan oleh Hasyim et al. (2017) yang melaporkan ekstrak daun biduri efektif sebagai bioakarisida terhadap tungau kuning (Polyphagotarsonemus latus) pada tanaman cabai.

Penurunan populasi gurem pada ayam buras setelah pengujian akarisida disebabkan gurem mati setelah terpapar perlakuan. Penurunan populasi gurem dapat juga dapat diakibatkan gurem lainnya yang mungkin tidak mati berpindah ke lingkungan lain karena terganggu dengan paparan akarisida yang diuji. Persentase reduksi gurem pada kontrol negatif yang berbeda nyata dengan perlakuan lainnya menunjukan penurunan populasi gurem dipengaruhi oleh zat aktif yang terkandung di dalam larutan dan tidak dipengaruhi oleh proses perendaman. 


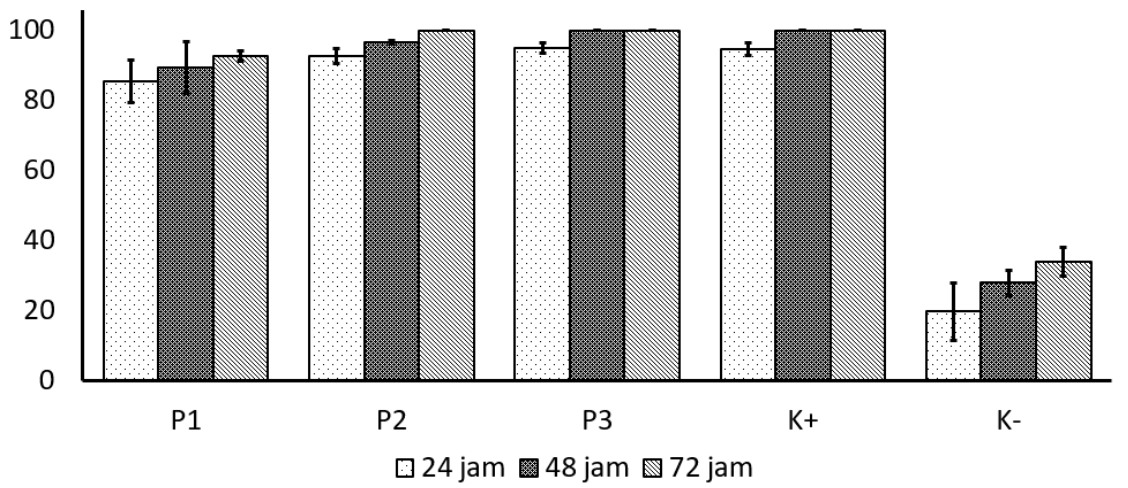

Gambar 1. Persentase reduksi gurem setelah pengujian akarisida

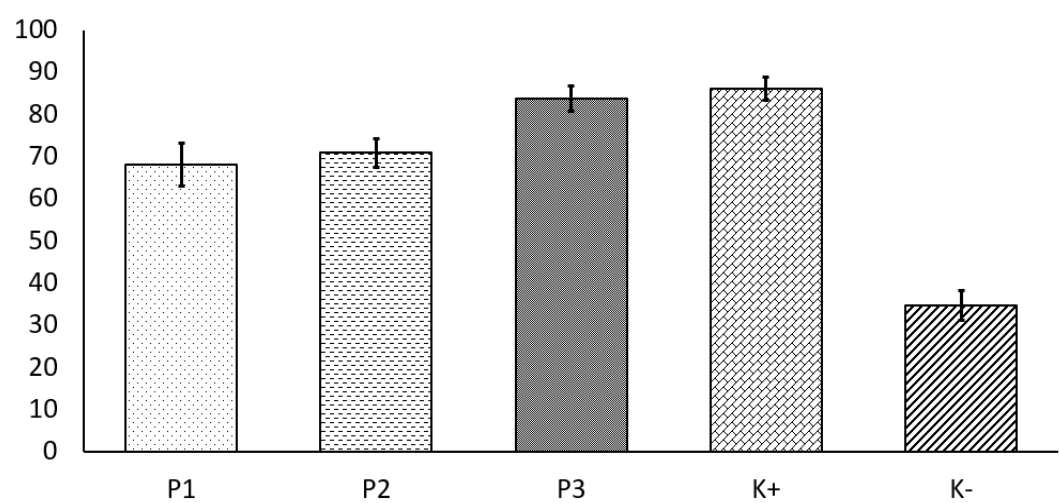

Gambar 2. Persentase reduksi aktivitas preening setelah pengujian akarisida

\section{Hasil Pengamatan Perilaku}

Hasil pengamatan perilaku menunjukan terdapat penurunan jumlah aktivitas preening pada semua kelompok perlakuan setelah pengujian akarisida (Tabel 3). Persentase reduksi aktivitas preening tertinggi terdapat pada kelompok kontrol positif yaitu sebesar $86.15 \%$, sementara persentase reduksi aktivitas preening terendah terdapat pada kelompok kontrol negatif yaitu sebesar $34.63 \%$ (Gambar 2). Persentase reduksi aktivitas preening pada kelompok perlakuan ekstrak daun biduri masing-masing adalah $68.02 \%$ untuk P1 (2 g/l), 70.89\% untuk P2 (4 g/l), dan 83.81\% untuk P3 (6 g/l).

Pengamatan perilaku preening penting dilakukan sebab infestasi ektoparasit berhubungan erat dengan perilaku preening pada ayam. Aktivitas preening kerap dilakukan untuk membersihkan diri dari kotoran dan mengusir ektoparasit yang bersembunyi di balik bulu. Perilaku preening sering diikuti dengan aktivitas menggaruk kepala dengan menggunakan kaki (Iskandar et al., 2009). Peningkatan perilaku preening diiringi infestasi ektoparasit yang tinggi merupakan respon pertahanan tubuh terhadap infestasi ektoparasit (Karma et al., 2015). Peningkatan preening bertujuan mengurangi jumlah ektoparasit (Clayton et al., 2010).

Infestasi ektoparasit termasuk gurem dapat meningkatkan aktivitas preening sehingga pengamatan perilaku preening penting untuk mengetahui pengaruh pengujian akarisida terhadap infestasi gurem. Berdasarkan hasil pengamatan, penurunan preening pada semua kelompok perlakuan memiliki hubungan dengan penurunan jumlah infestasi gurem pada ayam setelah pengujian akarisida. Hasil pengamatan aktivitas menelisik bulu setelah pengujian akarisida menunjukan perlakuan ekstrak daun biduri 6 g/l (P3) dapat dikembangkan menjadi bioakarisida karena memiliki daya reduksi aktivitas preening yang tidak berbeda nyata dengan kontrol positif berupa akarisida sintetik.

\section{KESIMPULAN}

Berdasarkan hasil penelitian dapat disimpulkan konsentrasi ekstrak daun biduri 6 
$\mathrm{g} / 1$ efektif mereduksi populasi gurem pada ayam buras hingga $100 \%$ dalam 48 jam dan mereduksi aktivitas preening hingga $83.81 \%$ setelah pengujian akarisida. Dengan demikian, ekstrak daun biduri berpontensi dikembangkan sebagai bioakarisida terhadap infestasi gurem pada ayam buras.

\section{UCAPAN TERIMA KASIH}

Penulis mengucapkan terima kasih kepada Direktorat Jenderal Pembelajaran dan Kemahasiswaan Kementerian Riset, Teknologi, dan Pendidikan Tinggi yang telah mendanai penelitian ini melalui hibah Program Kreativitas Mahasiswa tahun 2019. Penulis juga mengucapkan terima kasih kepada semua pihak yang telah membantu penulis selama kegiatan penelitian ini. Ucapan terima kasih secara khusus juga ditujukan kepada seluruh staf dan pegawai Laboratorium Entomologi Fakultas Kedokteran Hewan IPB, Laboratorium Farmasi Veteriner Fakultas Kedokteran Hewan IPB, Pusat Antar Universitas IPB, Balai Penelitian Tanaman Obat dan Rempah, serta Laboratorium Lapang Ilmu Nutrisi Ternak Unggas Fakultas Peternakan IPB.

\section{DAFTAR PUSTAKA}

[KEMENTAN] Kementerian Pertanian. 2014. Manual Penyakit Unggas. Direktorat Kesehatan Hewan Kementerian Pertanian, pp: 202-206.

[KOMPES] Komisi Pestisida. 2012. Metode Standar Pengujian Efikasi Pestisida Rumah Tangga dan Pengendalian Vektor. Komisi Pestisida, pp: 1-2.

Agnetha, A. 2008. Efek Ekstrak Bawang Putih (Allium sativum L.) Sebagai Larvasida Nyamuk Aedes aegypti sp.. [Skripsi]. Universitas Brawijaya.

Anggraini, D. 2006. Studi Efikasi Ekstrak Daun

Kisampang (Melicope denhamii) terhadap Ektoparasit pada Ayam Kampung yang ada di Bagian Dada. [Skripsi]. Fakultas Kedokteran Hewan. Institut Pertanian Bogor.

Axtell, R.C., Arends, J.J. 1990. Ecology and management of arthropod pests of poultry. Ann. Rev. Entomol., 35(1), 101-126.

Clayton, D.H., Koop, J.A.H., Harbison, C.W., Moyer, B.R., Bush, S.E. 2010. How Birds Combat Ectoparasites. Open Ornithol. J., 310(41), 41-71.

Dirganaya, I.W., Sumiartha, I.K., Adnyana, I.M.M. 2017. Efikasi Insektisida Berbahan Aktif (klorpirifos $540 \mathrm{~g} / \mathrm{l}$ dan sipermetrin 60 g/l) terhadap Perkembangan Populasi dan Serangan Hama Penggulung Daun Lamprosema indicata Fabricius (Lepidoptera: Pyralidae) pada Tanaman Kedelai. J. Agroekoteknol. Trop., 6(4), 378388.

Hadi, U.K., Soviana, S. 2010. Ektoparasit: Pengenalan, Identifikasi, dan Pengendaliannya. IPB Press, pp: 1-6.

Haditomo, I. 2010. Efek Larvasida Ekstrak Daun Cengkeh (Syzygium aromaticum L.) terhadap Aedes aegypti. [Skripsi]. Universitas Sebelas Maret.

Hasyim, A., Setiawati, W., Marhaeni, L.S., Lukman, L., Hudayya, A. 2017. Bioaktivitas Enam Ekstrak Tumbuhan untuk Pengendalian Hama Tungau Kuning Cabai Polyphagotarsonemus latus Bank (Acari: Tarsonemidae) di Laboratorium. J. Hort., 27(2), 217-230.

Iskandar, S., Setyaningrum, S.D., Amanda, Y., Soesanto, I. 2009. Pengaruh Kepadatan Kandang terhadap Pertumbuhan dan Perilaku Ayam Wereng-Tangerang Dara. JITV, 14(1), 19-24.

Karma, L., Haryono, T., Ambarwati, R. 2015. Keberadaan Arthropoda Ektoparasit pada Agapornis fischeri dan Hubungannya dengan 
Frekuensi Preening. Lentera Biol., 4(3), 150154.

Krantz, G.W. 1978. A Manual of Acarology. Corvallis. Oregon State University, pp: 509.

Kumar, P.S., Suresh, E., Kalavathy, S. 2013. Review on a potential herb Calotropis gigantea. Sch. Acad. J. Pharm., 2(2), 135143.

Nugroho, E.P. 2014. Efikasi Insektisida Sipermetrin terhadap Larva Caplak Boophilus microplus dari Desa Pangumbahan Kecamatan Ciracap Kabupaten Sukabumi. [Skripsi]. Fakultas Kedokteran Hewan. Institut Pertanian Bogor.
Prelezov, P. 2008. Comparative testing of some insecticides for control of mallophagosis in chickens. Trakia J. Sci., 6, 78-81.

Setiawan, Y.Y. 2013. Efektivitas Sipermetrin Terhadap Kutu Menopon gallinae dengan Metode Pemyemprotan pada Ayam Petelur. [Skripsi]. Fakultas Kedokteran Hewan. Institut Pertanian Bogor.

Widawati, M., Prasetyowati, H. 2013. Efektivitas Ekstrak Buah Beta vulgaris L. (Buah Bit) dengan Berbagai Fraksi Pelarut terhadap Mortalitas Larva Aedes aegypti. Aspirator, 5(1), 23-29. 